\title{
PENENTUAN PRODUK PROSPEKTIF DARI TIGA PRODUK UNGGULAN OLAHAN KELAPA DI KABUPATEN INDRAGIRI HILIR, RIAU
}

\author{
Hermiza Mardesci( $^{(1)}$, Santosa ${ }^{(2)}$, Novizar Nazir ${ }^{(3)}$, Rika Ampuh Hadiguna ${ }^{(4)}$ \\ ${ }^{(1)}$ Dosen Teknologi Pangan UNISI \\ mimzaaci@yahoo.co.id \\ ${ }^{(2)}$ Dosen Teknologi Pertanian Universitas Andalas Padang \\ santosa764@yahoo.co.id \\ ${ }^{(3)}$ Dosen Teknologi Pertanian Universitas Andalas Padang \\ nazir_novizar@yahoo.com \\ ${ }^{(4)}$ Dosen Teknik Industri Universitas Andalas Padang \\ hadiguna10@gmail.com
}

\begin{abstract}
Abstrak
Indragiri Hilir merupakan salah satu kabupaten di Riau yang menghasilkan cukup banyak kelapa. Kelapa tersebut berpotensi untuk dilakukan pengolahan lebih lanjut untuk menghasilkan berbagai macam produk olahan. Pada tulisan ini akan membahas kajian pengembangan agroindustri kelapa, yang meliputi pemilihan alternatif produk olahan komoditas kelapa.

Penentuan kriteria dan alternatif produk olahan kelapa pada penelitian ini dilakukan dengan studi pustaka dan diskusi dengan pakar. Wawancara dengan menggunakan kuisioner dilakukan terhadap pakar untuk mengetahui preferensi pakar terhadap alternatif berdasarkan kriteria yang telah ditentukan. Wawancara dilakukan terhadap tiga orang pakar, yang meliputi akademisi, tenaga penyuluh, dan pendamping kelompok tani.

Metode pengolahan data pada penelitian ini adalah dengan menggunakan teknik fuzzy group decision making, pengambilan keputusan kelompok secara fuzzy dengan preferensi independen menggunakan multi expert multi criteria decision making (ME-MCDM).Dari hasil analisis dengan menggunakan teknik fuzzy non numeric decision making diperoleh produk yang prospektif untuk dikembangkan adalah minyak kelapa.
\end{abstract}

Kata kunci : ME-MCDM, fuzzy logic, produk olahan kelapa

\section{PENDAHULUAN}

Indragiri Hilir merupakan salah satu Kabupaten di Riau yang menghasilkan cukup banyak kelapa. Menurut data statistik, produksi kelapa dalam di Indragiri Hilir mencapai $390.924,28$ ton per tahun dengan luas lahan 295.380,24 Ha. Untuk kelapa hybrida tercatat produksi sebanyak $67.055,69$ ton dari luas lahan 28.770 ton.
Dengan potensi tersebut membuat Kabupaten Indragiri Hilir tercatat sebagai salah satu daerah kelapa terbesar di dunia, bahkan dijuluki sebagai Tanah Hamparan Kelapa Dunia (BP2MPD Inhil, 2015). Pada tahun 2014, produksi kelapa dalam mencapai 566.755 Ton (Kabupaten Indragiri Hilir dalam Angka, 2015). 
Tanaman kelapa (Cocos nucifera L.) merupakan tanaman yang sangat berguna dalam kehidupan ekonomi pedesaan di Indonesia. Karena semua bagian dari pohon kelapa dapat dimanfaatkan untuk memenuhi kebutuhan manusia. Salah satu bagian kelapa yang mempunyai banyak manfaat adalah daging buah (Palungkun, 2004).

Kelapa merupakan komoditas perkebunan yang memiliki banyak nilai ekonomis. Hampir semua bagian dari kelapa memiliki manfaat untuk berbagai keperluan. Daging buah kelapa dapat diolah menjadi kopra, virgin coconut oil (VCO), minyak kelapa, kelapa parut, santan, tepung kelapa. Sabut dapat diolah menjadi kerajinan tangan, matras, tali, jok mobil, genteng, karpet, cocofiber (serat sabut kelapa), dan cocopeat (serbuk sabut kelapa). Air kelapa dapat diolah menjadi nata de coco.

Agroindustri kelapa merupakan industri berbasis pada sumber daya lokal dan merupakan salah satu usaha yang menjadi tumpuan pendapatan masyarakat Indragiri Hilir. Namun, pengembangan agroindustri kelapa ini belum sepenuhnya menghasilkan keuntungan yang maksimal. Hal ini disebabkan karena belum adanya kajian mengenai produk dari olahan komoditas kelapa yang prospektif untuk dikembangkan.

Penelitian ini bertujuan untuk menentukan produk olahan komoditas kelapa yang prospektif untuk dikembangkan di Indragiri Hilir.

\section{METODOLOGI}

Penentuan kriteria dan alternatif produk olahan kelapa pada penelitian ini dilakukan dengan studi pustaka dan diskusi dengan pakar. Wawancara dengan menggunakan kuisioner dilakukan terhadap pakar untuk mengetahui preferensi pakar terhadap alternatif berdasarkan kriteria yang telah ditentukan. Wawancara dilakukan terhadap tiga orang pakar, yang meliputi akademisi, tenaga penyuluh, dan pendamping kelompok tani.

Metode pengolahan data pada penelitian ini adalah dengan menggunakan teknik fuzzy group decision making, pengambilan keputusan kelompok secara fuzzy dengan preferensi independen menggunakan multi expert multi criteria decision making (MEMCDM).

Multi Exper - Multi Criteria Decision Making (ME-MCDM) merupakan suatu metode pengambilan keputusan dengan berbagai macam kriteria yang disediakan. Pengembilan keputusan tersebut dilakukan untuk mencari alternatif paling baik berdasarkan pendapat pakar (expert) yang tertuang dalam bentuk non-numeric (secara kualitatif) terhadap situasi yang dihadapi (Marimin, 2004).

ME-MCDM merupakan salah satu model dalam pengambilan keputusan yang dikembangkan oleh Yager (1993). Dalam komponen keputusan, terdapat yang disebut dengan alternatif keputusan, kriteria keputusan, bobot kriteria, model penilaian, model perhitungan, dan tipe pengambil keputusan.

Prosedur kerja pengambilan keputusan ME-MCDM adalah ; (1) Agregasi kriteria, dan (2) Agregasi pakar). Prosedur non numeric MEMCDM tersebut dapat dilihat pada Gambar 1.

Sebelum pengambilan keputusan dengan ME-MCDM, terlebih dahulu dilakukan langkah berikut :

1. Menentukan alternatif dan kriteria untuk analisis produk olahan kelapa yang akan dikembangkan 
2. Menetapkan label linguistik $\mathrm{ST}=$ Sangat Tinggi

(Nilai 5) preferensi fuzzy non numeric,

$\mathrm{T}=$ Tinggi

(Nilai 4)

preferensi multi person terhadap

$\mathrm{S}=$ Sedang

(Nilai 3)

suatu kriteria diberikan dengan

$\mathrm{R}=$ Rendah

(Nilai 2)

penilaian skala ordinal dengan 5

$\mathrm{SR}=$ Sangat Rendah

(Nilai 1) skala.

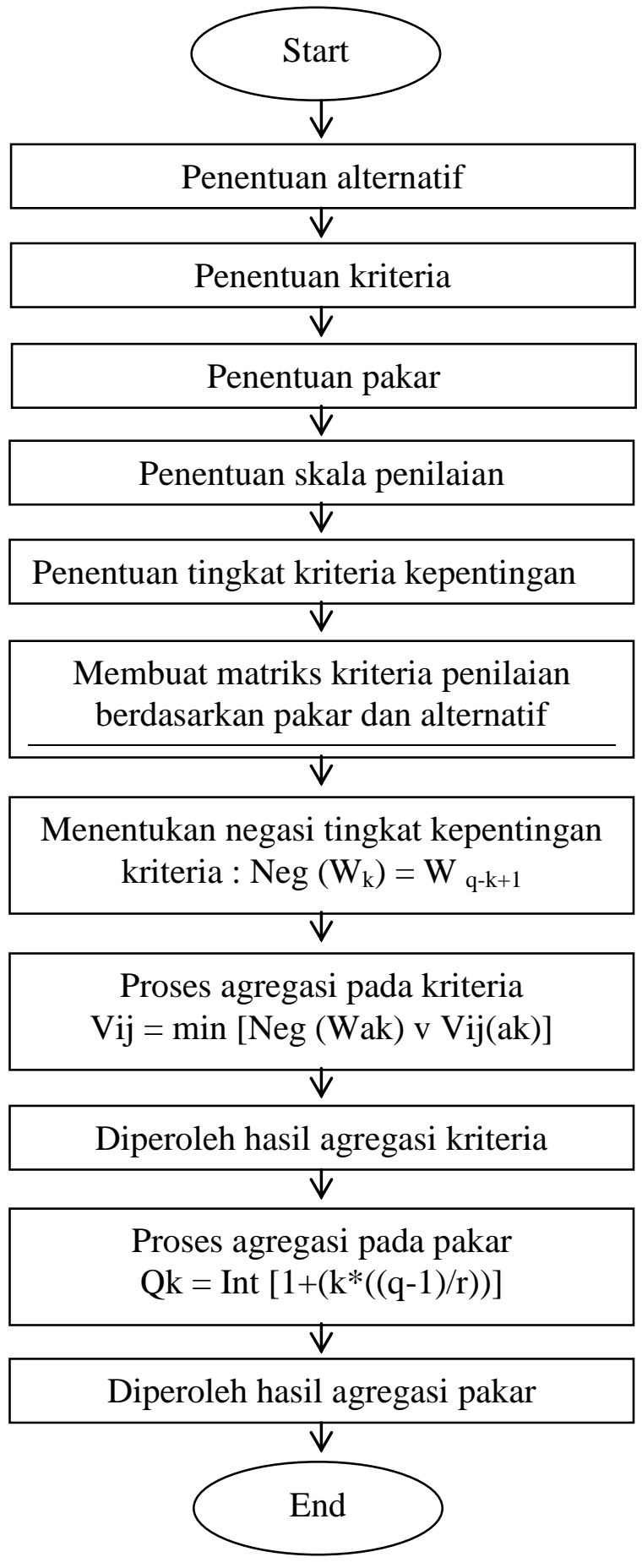

Gambar 1. Prosedur Non Numeric ME-MCDM 
3. Memilih pakar untuk melakukan penilaian setiap alternatif berdasarkan kriteria dalam analisis produk olahan komoditas kelapa yang akan dikembangkan.

4. Menentukan bobot masing-masing kriteria dengan menggunakan metode Analysis Hierarchy Process (AHP).

Setelah langkah-langkah tersebut dilakukan, selanjutnya dilakukan prosedur pengambilan keputusan dengan ME-MCDM.

Agregasi kriteria dilakukan dengan terlebih dahulu menentukan negasi tingkat kepentingan kriteria dengan formula : $\operatorname{Neg}\left(W_{k}\right)=W_{q-k+1}$

Selanjutnya dilakukan agregasi kriteria dengan menggunakan formula :

$$
V_{i j}=\min \left[\operatorname{Neg}\left(W_{a k}\right) v V_{i j}\left(a_{k}\right)\right]
$$

Setelah agregasi kriteria selesai, selanjutnya dilakukan agregasi pakar. Agregasi pakar dilakukan dengan menggunakan formula :

$$
Q_{k}=\operatorname{Int}\left[1+\left(k * \frac{q-1}{r}\right)\right]
$$

\section{HASIL DAN PEMBAHASAN}

\section{Alternatif dan Kriteria Pengembangan Produk Olahan Komoditas Kelapa}

Dari hasil studi pustaka dan diskusi pakar, maka dapat diperoleh 3 alternatif produk olahan komoditas kelapa yang dapat dikembangkan di Kabupaten Indragiri Hilir. Produk olahan tersebut adalah, minyak kelapa, gula kelapa, dan arang aktif.

Minyak kelapa merupakan bagian paling berharga dari buah kelapa. Kandungan minyak pada daging buah kelapa tua sebanyak 34,7\%. Minyak kelapa digunakan sebagai bahan baku industri atau sebagai minyak goreng. Minyak kelapa dapat diekstrak dari daging kelapa segar atau diekstrak dari daging kelapa yang telah dikeringkan atau yang biasa disebut kopra (Tarwiyah, 2001).

Gula kelapa merupakan bahan pangan yang terbuat dari nira kelapa. Nira kelapa adalah cairan manis yang diperoleh dengan melakukan perlakuan khusus terhadap manggar kelapa (spatha) yang belum membuka pada umur tertentu (Setyamidjaja, 1991). Prinsip pembuatan gula merah kelapa adalah menguapkan air dalam nira sampai kekentalan tertentu, kemudian nira kental dicetak menggunakan cetakan (Suhardiyono, 1991).

Arang tempurung kelapa adalah produk yang diperoleh dari pembakaran tidak sempurna terhadap tempurung kelapa. Sebagai bahan bakar, arang lebih menguntungkan dibanding kayu bakar. Arang memberikan kalor pembakaran yang lebih tinggi, dan asap yang lebih sedikit.

Pemilihan produk prospektif tersebut berdasarkan beberapa kriteria, yang antara lain : ketersediaan bahan baku, penyerapan tenaga kerja, teknologi yang digunakan, nilai tambah produk, dampak lingkungan, peluang pasar, mutu produk, distribusi produk, dan kebijakan pemerintah.

\section{Penilaian Setiap Alternatif Berdasarkan Kriteria}

Dari hasil penilaian pakar terhadap alternatif berdasarkan masing-masing kriteria diperoleh hasil pada tabel 1, 2, dan 3 .

Dari tabel 1, 2, dan 3 dapat dilihat penilaian masing-masing pakar terhadap tiga alternatif produk berdasarkan 9 kriteria yang telah ditentukan. Penilaian pakar I, II, dan III menunjukkan bahwa alternatif produk minyak kelapa memiliki nilai lebih tinggi pada beberapa 
kriteria dibandingkan dengan produk gula kelapa dan arang aktif.

Tabel 1. Penilaian Alternatif Berdasarkan Kriteria oleh Pakar I

\begin{tabular}{|l|c|c|c|}
\hline Kriteria Alternatif & Minyak Kelapa & Gula Kelapa & Arang Aktif \\
\hline Ketersediaan bahan baku & $\mathrm{ST}$ & $\mathrm{T}$ & $\mathrm{S}$ \\
\hline Penyerapan tenaga kerja & $\mathrm{T}$ & $\mathrm{T}$ & $\mathrm{T}$ \\
\hline Teknologi yang digunakan & $\mathrm{ST}$ & $\mathrm{S}$ & $\mathrm{S}$ \\
\hline Nilai tambah produk & $\mathrm{ST}$ & $\mathrm{T}$ & $\mathrm{ST}$ \\
\hline Dampak lingkungan & $\mathrm{S}$ & $\mathrm{T}$ & $\mathrm{T}$ \\
\hline Peluang pasar & $\mathrm{S}$ & $\mathrm{S}$ & $\mathrm{ST}$ \\
\hline Mutu produk & $\mathrm{S}$ & $\mathrm{T}$ & $\mathrm{T}$ \\
\hline Distribusi produk & $\mathrm{S}$ & $\mathrm{T}$ & $\mathrm{T}$ \\
\hline Kebijakan pemerintah & $\mathrm{T}$ & $\mathrm{S}$ & $\mathrm{S}$ \\
\hline
\end{tabular}

Tabel 2. Penilaian Alternatif Berdasarkan Kriteria oleh Pakar II

\begin{tabular}{|l|c|c|c|}
\hline Kriteria Alternatif & Minyak Kelapa & Gula Kelapa & Arang Aktif \\
\hline Ketersediaan bahan baku & ST & T & S \\
\hline Penyerapan tenaga kerja & ST & S & T \\
\hline Teknologi yang digunakan & ST & S & R \\
\hline Nilai tambah produk & ST & ST & ST \\
\hline Dampak lingkungan & T & T & T \\
\hline Peluang pasar & ST & ST & ST \\
\hline Mutu produk & ST & ST & ST \\
\hline Distribusi produk & ST & ST & S \\
\hline Kebijakan pemerintah & ST & S & S \\
\hline
\end{tabular}

Tabel 3. Penilaian Alternatif Berdasarkan Kriteria oleh Pakar III

\begin{tabular}{|l|c|c|c|}
\hline Kriteria Alternatif & Minyak Kelapa & Gula Kelapa & Arang Aktif \\
\hline Ketersediaan bahan baku & $\mathrm{T}$ & $\mathrm{T}$ & $\mathrm{T}$ \\
\hline Penyerapan tenaga kerja & $\mathrm{T}$ & $\mathrm{T}$ & $\mathrm{T}$ \\
\hline Teknologi yang digunakan & $\mathrm{S}$ & $\mathrm{R}$ & $\mathrm{R}$ \\
\hline Nilai tambah produk & $\mathrm{T}$ & $\mathrm{T}$ & $\mathrm{T}$ \\
\hline Dampak lingkungan & $\mathrm{R}$ & $\mathrm{R}$ & $\mathrm{S}$ \\
\hline Peluang pasar & $\mathrm{T}$ & $\mathrm{T}$ & $\mathrm{T}$ \\
\hline Mutu produk & $\mathrm{T}$ & $\mathrm{S}$ & $\mathrm{S}$ \\
\hline Distribusi produk & $\mathrm{R}$ & $\mathrm{R}$ & $\mathrm{R}$ \\
\hline Kebijakan pemerintah & $\mathrm{T}$ & $\mathrm{R}$ & $\mathrm{R}$ \\
\hline
\end{tabular}

Secara umum dapat dilihat, adalah penilaian terendah untuk semua penilaian alternatif oleh pakar I alternatif produk. Meskipun begitu, berdasarkan kebijakan pemerintah alternatif produk minyak kelapa masih 
memiliki nilai lebih tinggi dibanding dua produk lainnya.

Penilaian alternatif oleh pakar II dan pakar III berdasarkan kebijakan pemerintah juga memiliki nilai yang rendah. Tidak jauh berbeda dengan penilaian oleh pakar I, bahwa alternatif produk minyak kelapa memiliki nilai yang lebih baik dibanding dua produk lainnya.

Penilaian oleh pakar III yang paling rendah adalah berdasarkan dsitribusi produk. Untuk ketiga alternatif produk, pakar III membarikan penilaian yang rendah berdasarkan kriteria distribusi produk.

\section{Penentuan Bobot Kriteria}

Pemilihan kriteria ini berdasarkan analisis pakar dan pengorganisasian dari berbagai literatur tentang kelapa, yang menyatakan bahwa dalam menentukan produk agroindustri kelapa dapat didasarkan pada 9 kriteria, yaitu; ketersediaan bahan baku, penyerapan tenaga kerja, teknologi yang digunakan, nilai tambah produk, dampak lingkungan, peluang pasar, mutu produk, distribusi produk, dan kebijakan pemerintah.

Pembobotan kesembilan kriteria tersebut dilakukan dengan menggunakan metode AHP dengan mengambil pendapat dari pakar yang digabungkan dengan literatur. Nilai bobot masingmasing kriteria dan negasinya dapat dilihat pada Tabel 4.

Tabel 4. Kriteria, Bobot Kriteria, dan Negasinya

\begin{tabular}{|l|l|c|c|c|}
\hline No & \multicolumn{1}{|c|}{ Kriteria } & Bobot & Label & Negasi \\
\hline 1 & Ketersediaan bahan baku & 0,270 & $\mathrm{ST}$ & $\mathrm{SR}$ \\
2 & Penyerapan tenaga kerja & 0,087 & $\mathrm{~S}$ & $\mathrm{~S}$ \\
3 & Teknologi yang digunakan & 0,069 & $\mathrm{R}$ & $\mathrm{T}$ \\
4 & Nilai tambah produk & 0,111 & $\mathrm{~T}$ & $\mathrm{R}$ \\
5 & Dampak lingkungan & 0,026 & $\mathrm{SR}$ & $\mathrm{ST}$ \\
6 & Peluang pasar & 0,113 & $\mathrm{~T}$ & $\mathrm{R}$ \\
7 & Mutu produk & 0,206 & $\mathrm{ST}$ & $\mathrm{S}$ \\
8 & Distribusi Produk & 0,036 & $\mathrm{SR}$ & $\mathrm{ST}$ \\
9 & Kebijakan pemerintah & 0,082 & $\mathrm{~S}$ & $\mathrm{~S}$ \\
\hline
\end{tabular}

Dari tabel 4 dapat dilihat bahwa bobot tertinggi terdapat pada kriteria ketersediaan bahan baku, yang diikuti oleh kriteria mutu produk. Oleh karena itu kedua kriteria ini diberi label Sangat Tinggi (ST), dengan negasi Sangat Rendah (SR).

Sedangkan bobot terendah terdapat pada kriteria distribusi produk dan kriteria dampak lingkungan. Oleh karena itu kedua kriteria ini diberi label Sangat
Rendah (SR), dengan negasi Sangat Tinggi (ST).

\section{Agregasi Kriteria}

Untuk menentukan agregasi kriteria maka terlebih dahulu ditentukan bobot kriteria dan negasi bobot kriteria seperti telihat pada tabel 4. Selanjutnya dilakukan perhitungan pada masingmasing alternatif. Hasil perhitungan masing-masing alternatif adalah sebagai berikut : 


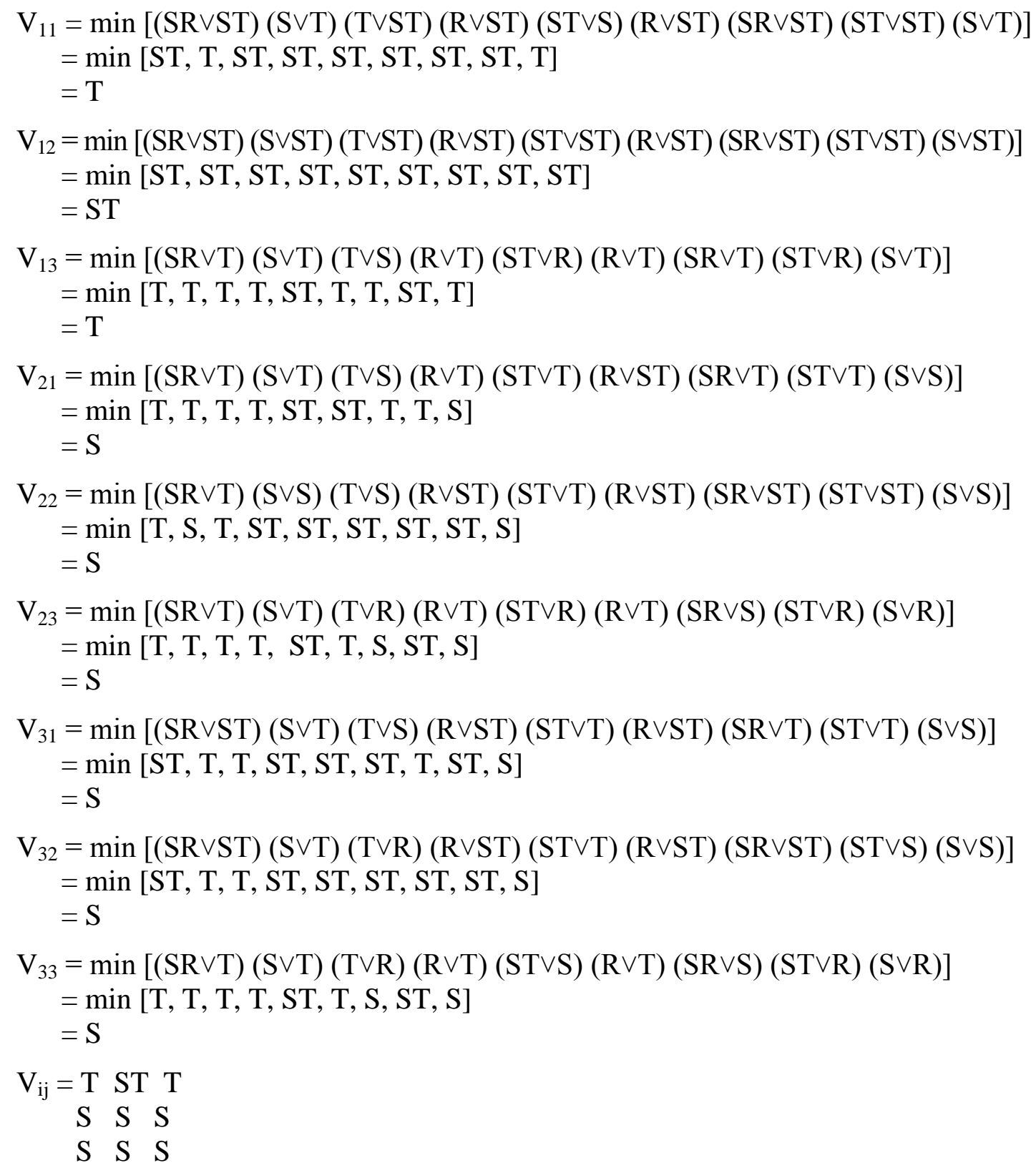

Dari hasil penilaian alternatif tersebut dapat dilihat bahwa penilaian oleh pakar I mempelihatkan nilai Tinggi (T) untuk alternatif produk minyak kelapa, nilai Sangat Tinggi (ST) untuk alternatif produk gula kelapa, dan nilai Tinggi (T) untuk alternatif produk arang kelapa.

Penilaian oleh pakar II dan III memperlihatkan nilai yang sama untuk ketiga alternatif produk, yaitu dengan nilai Sedang $(\mathrm{S})$.

\section{Agregasi Pakar}

Sebelum melakukan agregasi pakar maka dilakukan penentuan bobot nilai pakar dengan menggunakan formula : $\mathrm{Qk}=\operatorname{Int}\left[1+\left(\mathrm{k}^{*}((\mathrm{q}-1) / \mathrm{r})\right)\right]$

$\mathrm{Q}_{1}=\operatorname{Int}[1+(1 \times((5-1) / 3))]=2=\mathrm{R}$

$\mathrm{Q}_{2}=\operatorname{Int}[1+(2 \times((5-1) / 3))]=4=\mathrm{T}$

$\mathrm{Q}_{3}=\operatorname{Int}[1+(3 \times((5-1) / 3))]=5=\mathrm{ST}$ 
Agregasi pakar dilakukan dengan menggunakan formula :

$$
\begin{aligned}
\mathrm{V}_{\mathrm{i}} & =\mathrm{f}\left(\mathrm{V}_{\mathrm{i}}\right) \operatorname{Maks}\left[\mathrm{Q}_{\mathrm{j}} \wedge \mathrm{b}_{\mathrm{j}}\right] \\
\mathrm{V}_{1} & =\operatorname{maks}[(\mathrm{R} \wedge \mathrm{T})(\mathrm{T} \wedge \mathrm{ST})(\mathrm{ST} \wedge \mathrm{T})] \\
& =\operatorname{maks}[\mathrm{R}, \mathrm{T}, \mathrm{T}] \\
& =\mathrm{T} \\
\mathrm{V}_{2} & =\operatorname{maks}[(\mathrm{R} \wedge \mathrm{S})(\mathrm{T} \wedge \mathrm{S})(\mathrm{ST} \wedge \mathrm{S})] \\
& =\operatorname{maks}[\mathrm{R}, \mathrm{S}, \mathrm{S}] \\
& =\mathrm{S} \\
\mathrm{V}_{3} & =\operatorname{maks}[(\mathrm{R} \wedge \mathrm{S})(\mathrm{T} \wedge \mathrm{S})(\mathrm{ST} \wedge \mathrm{S})] \\
& =\operatorname{maks}[\mathrm{R}, \mathrm{S}, \mathrm{S}] \\
& =\mathrm{S}
\end{aligned}
$$

Dari hasil analisis tersebut, menunjukkan bahwa alternatif pertama, yaitu minyak kelapa mempunyai nilai paling tinggi dibandingkan alternatif lain. Dimana nilai minyak kelapa adalah: Tinggi (T). Sedangkan dua alternatif produk lainnya memiliki nilai Sedang (S). Oleh sebab itu, dapat disimpulkan bahwa minyak goreng merupakan pilihan produk yang dapat dikembangkan pada industri olahan komoditas kelapa di Indragiri Hilir.

\section{KESIMPULAN DAN SARAN}

\section{Kesimpulan}

Dari hasil penelitian ini disimpulkan bahwa produk olahan kelapa yang prospektif dikembangkan adalah minyak kelapa. Penilaian ini berdasarkan 9 kriteria, yang terdiri dari ketersediaan bahan baku, penyerapan tenaga kerja, teknologi yang digunakan, nilai tambah produk, dampak lingkungan, peluang pasar, mutu produk, distribusi produk, dan kebijakan pemerintah. Penilaian ini juga berdasarkan pendapat 3 orang pakar, yang terdiri dari akademisi, tenaaga penyuluh pertanian, dan pendamping kelompok tani.

\section{Saran}

Diharapkan penelitian selanjutnya melibatkan lebih banyak pakar, termasuk pakar dari pengrajin kelapa, dan juga pemerintah. Selain itu penilaian sebaiknya dilakukan dengan alernatif produk yang lebih banyak. Hal ini bertujuan untuk mendapatkan hasil yang lebih akurat, karena produk olahan kelapa tidak hanya terdiri dari tiga olahan seperti yang dibahas pada penelitian ini.

\section{DAFTAR PUSTAKA}

Badan Perizinan, Penanaman Modal dan Promosi Daerah Inhil (BP2MPD). 2015. Investasi; Potensi Daerah Perkebunan.

www.bp2mpd.inhilkab.go.id.

Diunduh pada tanggal 12 November 2016.

Badan Pusat Statistik. 2015. Kabupaten Indragiri Hilir dalam Angka.

Marimin. 2004. Teknik dan Aplikasi Pengambilan Keputusan Kriteria Majemuk. Jakarta : Gramedia Widiasarana Indonesia.

Palungkun, R., 2004. Aneka Produk Olahan Kelapa. Jakarta.Penebar Swadaya.

Setyamidjaya, D. 1991. Bertanam Kelapa, Budidaya dan Pengolahannya. Yogyakarta : Penerbit Kanisius.

Suhardiyono, L. 1991. Tanaman Kelapa, Budidaya dan Pemanfaatannya. Yogyakarta : Penerbit Kanisius.

Tarwiyah, K. 2001. Minyak Kelapa.

Dewan Ilmu Pengetahuan.

Teknologi dan Industri Sumatera Barat. 